\title{
MANAJEMEN LAKTASI DAN PERTUMBUHAN USIA INFANT
}

\author{
Rukmini \\ Akademi Keperawatan Adi Husada Surabaya \\ rukmini.73@gmail.com
}

\begin{abstract}
ABSTRAK
Manajemen laktasi merupakan upaya yang dilakukan oleh ibu atau ayah dan keluarga untuk mendukung kesuksesan pemberian ASI. Produksi ASI yang optimal akan memberikan gizi yang optimal untuk pertumbuhan bayi. Tapi, banyak faktor yang dapat mempengaruhi produk manajemen laktasi seperti pengetahuan, perilaku, gizi ibu, dukungan tenaga kesehatan, dan dukungan keluarga dapat menurunkan nilai menyusui di Indonesia.Tujuan dari penelitian ini adalah untuk mengetahui hubungan manajemen laktasi dengan pertumbuhan bayi 0-6 bulan. Jenis penelitian ini adalah desain studi deskriptif kuantitatif-analitik dengan pendekatan cross sectional. Sampel penelitian ini adalah 41 responden yang dipilih dengan metode simple random sampling.Data dikumpulkan dengan kuesioner dan bayi berat lembar observasi dari KMS dengan skala ordinal untuk manajemen laktasi dan skala ordinal untuk pertumbuhan bayi 0-6 bulan. Data dianalisis dengan Spearman Rank Test. Hasil penelitian ini menunjukkan bahwa $63,41 \%$ responden berusia $20-29$ tahun, $48,78 \%$ berasal dari madura, 48,78\% berasal dari jawa, 85,37\% adalah ibu rumah tangga dengan 39,02\% dari hasil keluarga $>1.600 .000$ rupiah. $75,61 \%$ ibu memberikan manajemen laktasi yang baik, $95,12 \%$ bayi memiliki status gizi yang baik. Dalam statistik menunjukkan bahwa ada hubungan yang signifikan dari manajemen laktasi dengan pertumbuhan bayi 0-6 bulan dengan nilai $\rho=0,016(\rho<0,05)$. Dari penelitian ini, ibu yang memberikan manajemen laktasi yang baik belum mencapai maksimal, hal ini membutuhkan perhatian antara ibu, keluarga termasuk ayah, petugas kesehatan, kader kesehatan, dan pemerintah untuk mencapai nilai ASI eksklusif di Indonesia sampai dengan $80 \%$
\end{abstract}

Kata kunci: manajemen laktasi, pertumbuhan infant

\section{ABSTRACT}

Lactation management is an effort does by mother or father and family to support succesfull breastfeeding. Optimal breastfeeding production will give the baby an optimal nutrition for it growth. But, many factor that can influence lactation management product like knowledge , behaviour, nutrition of mothers, health worker's support, and family's support can decrease breastfeeding value in Indonesia. The aim from this research is to know correlation of lactation management with growth infants 0-6 months. This type of research is a quantitative-analitic descriptivestudy design with Cross Sectional approach. Sample of this research are 41 respondents which have been selected by simple random sampling method. Data was collected with questionnaire and infants weight observation sheets from KMS with ordinal scale for lactation management and ordinal scale for infants growth 0-6 months. Data was analyzed with Rank Spearman Test. Result of this research showed that 63,41\%of respondent were 20-29 years old, 48,78\% were from madura, 48,78\% were from jawa, 85,37\% were housewives with 39,02\%of family's outcome $>1.600 .000$ rupiahs. 75, 61\%of mothers giving a good lactation management, 95,12\% of infants have good nutrition status. In statistic showed that there are significant correlation of lactation management with growth infants $0-6$ months with $\rho$ values $=0,016$ $(\rho<0,05)$. From this research, mothers which are giving a good lactation management are not reaching the maximum rank yet, it means need an attention between mother, family including fathers, health workers, health cadres, and goverment to reach the exclusive breastfeeding value in Indonesia up to $80 \%$.

Keywords: Lactation Management, Growth Infants

\section{PENDAHULUAN}

ASI merupakan makanan pertama, utama dan terbaik bagi bayi yang bersifat alamiah. ASI eksklusif menurut World Health Organization (WHO) adalah ASI yang diberikan tanpa memberikan makanan dan minuman lain kepada bayi sejak lahir sampai berumur 6 bulan, kecuali obat dan vitamin. ${ }^{11}$ ASI mengandung banyak manfaat dan kelebihan antara lain steril, selalu tersedia dengan suhu yang optimal, produksi disesuaikan dengan kebutuhan bayi, mengandung antibodi yang dapat menghambat pertumbuhan atau membunuh kuman, dan tidak 
ada bahaya alergi. ASI juga mengandung kolostrum yang berguna untuk imunitas tubuh dan protein yang lebih rendah dari susu sapi, mengandung karbohidrat yang relatif lebih tinggi dari susu sapi dan kadar lemak yang relatif sama dengan susu sapi. Disamping itu ASI mengandung mineral yang lengkap, $88 \%$ terdiri dari air dan vitamin A,D,C yang cukup.

Cakupan ASI eksklusif di Indonesia berfluktuasi mulai tahun 2002-2012. Menurut Data Riset Kesehatan Dasar (Riskedas) tahun 2013 dan SDKI tahun 2012 menunjukkan cakupan ASI di Indonesia hanya $42 \%$. Berdasarkan laporan yang diterima dari Dinas Kesehatan (Dinkes) Provinsi tahun 2013 diketahui bahwa cakupan pemberian ASI secara eksklusif tahun 2013 adalah sebesar $54,3 \%$ dari target sebesar $75 \%$.

Berdasarkan profil kesehatan Indonesia terbaru tahun 2014, di Jawa Timur sendiri hanya $74 \%$ dari 247.990 bayi yang mendapatkan ASI ekslusif. Sedangkan cakupan ASI di wilayah Surabaya khusunya di Puskesmas Peneleh hanya mencapai angka 43\% dari 246 bayi usia 0-6 bulan. Angka pencapaian ini masih kurang dari target nasional yaitu $80 \%$.

Banyak factor yang mempengaruhi pencapaian Asi masih berfluktuatif antara lain berdasarkan penelitian Sri Handini Pertiwi tahun 2012 tentang faktor yang mempengaruhi proses laktasi ibu dengan usia 0-6 bulan di desa Cibeusi kecamatan Jatinangor, menyebutkan bahwa permasalah ibu menyusui antara lain adalah puting susu yang luka dan masalah penempelan mulut bayi ke payudara. Masih terdapat sebagian besar ibu yang berhenti menyusui di minggu kedua setelah melahirkan bukan karena faktor nyeri payudara saat menyusui, bayi sulit menghisap karena kesalahan posisi, serta penjadwalan pemberian ASI karena menganggap bahwa menyusui merupakan kegiatan yang menghabiskan waktu. Fakta diatas menunjukan bahwa managemen laktasi sangat dibutuhkan untuk meningkatkan pancapaian cakupan ASI eksklusif di Indonesia. Keberhasilan managemen laktasi membutuhkan berbagai faktor pendukung. Seperti pada penelitian yang dilakukan oleh Sulimah Hamadun tahun 2013 tentang determinan sosial mempengaruhi manajemen laktasi pada ibu hamil didapatkan data adanya hubungan antara pengetahuan, kepatuhan ibu , dukungan suami, peran pelayanan kesehatan, kemampuan petugas, dan budaya lokal dengan pelaksanaan manajemen laktasi. Mengutip penelitian dari A.Bekti Rahayu tentang hubungan tingkat pendidikan ibu dengan komitmen pemberian ASI ekslusif tahun 2015 menyebutkan, hanya $34 \%$ ibu yang menyusui secara eksklusif selama enam bulan. Sedangkan pada penelitian tentang masalah dan strategi peningkatan cakupan ASI eksklusif di Indonesia oleh Ratih Putih tahun 2015 menyatakan bahwa dari hasil Riskesdas 2013, pemberian ASI pada bayi dibawah 6 bulan belum memuaskan. Pemberian ASI pada umur 0 bulan sebesar 39,8\%, 1 bulan sebesar 32,5\%, 2 bulan sebesar $30,7 \%, 3$ bulan sebesar $25,2 \%$, 4 bulan sebesar $26,3 \%$, dan 5 bulan sebesar $15,3 \%$.

Kegagalan dalam proses manajemen laktasi dapat menyebabkan ibu menjadi stres dan ASI tidak akan diproduksi dengan baik. Akibatnya, bayi akan haus dan merasa tidak puas. Jika hal ini terjadi terus menerus akan menganggu asupan nutrisi dari bayi tersebut. Nutrisi yang tidak terpenuhi akan menghambat proses pertumbuhan khususnya penambahan berat badan bayi. Berat badan bayi harus bertambah $1 \mathrm{~kg} /$ bulan untuk 6 bulan pertama. Jika ada bayi dibawah usia 6 bulan tidak mendapatkan berat badan yang ideal, maka bayi tersebut harus lebih sering disusui. ${ }^{9}$

Proses menyusui adalah saat yang penting bagi ibu pasca melahirkan. Proses menyusui dipengaruhi oleh faktor internal yaitu kondisi dan perawatan payudara ibu, keadaan psikis ibu, kesibukan ibu bekerja, kondisi bibir, palatum dan lidah bayi. Faktor eksternal yang juga dapat mempengaruhi ASI berasal dari lingkungan dan keluarga antara lain kebiasaan keluarga saat menyusui bayi, makanan prelaktat, promosi susu formula dan dukungan keluarga terutama suami. Proses menyusui yang bermasalah dapat menyebabkan ASI yang dikeluarkan tidak optimal dan dapat mengganggu pertumbuhan bayi. Oleh karena itu, masalah pada proses menyusui ini dapat diminimalisir dengan manajemen laktasi. Manajemen laktasi dimulai dari pemeriksaan payudara sampai pemberian ASI perasan. Dengan diterapkannya manajemen laktasi yang benar diharapkan akan mengatasi masalah seputar laktasi dan meningkatkan cakupan ASI eksklusif di Indonesia. Sehingga pertumbuhan pada bayi 0-6 bulan menjadi optimal tanpa makanan tambahan yang seharusnya tidak diberikan pada usia ini.

Tujuan penelitian ini adalah (1) Untuk mengidentifikasi manajemen laktasi pada ibu menyusui; (2) Untuk mengidentifikasi pertumbuhan bayiusia $0-6$ bulan; (3)Untuk 
menganalisishubungan manajemen laktasi dengan pertumbuhan bayi usia 0-6 bulan.

\section{METODE}

Desain penelitian yang digunakan adalah desain penelitian deskriptif analitik dengan pendekatan cross sectional. Penelitian ini dilaksanakan pada bulan Januari sd Juni 2016, di posyandu wilayah binaan Puskesmas Peneleh Kecamatan Genteng Kelurahan Peneleh Surabaya. Penelitian ini dimulai bersamaan dengan Hari Timbang Serentak. Posyandu yang menjadi lokasi penelitian terletak di perkampungan wilayah Peneleh dan Kapasari. Populasi adalah semua ibu yang memiliki bayi usia 0-6 bulan di wilayah binaan Puskesmas Peneleh Surabaya dengan jumlah 70 bayi. Sampel dalam penelitian ini yaitu sebagian ibu yang memiliki bayi usia 0-6 bulan d wilayah Puskemas Peneleh Surabaya dengan jumlah 41 bayi. Teknik pengambilan sampel pada penelitian ini menggunakan simple random sampling. Data di analisis secara deskriptif yaitu dalam bentuk tabel distribusi frekuensi dan tabel silang. Sedangkan untuk mengetahui ada tidaknya hubungan, menggunakan analisis inferensial yaitu uji statistik rank spearman dengan tingkat signifikasi $(\alpha=0,05)$.

\section{HASIL}

Penelitian ini dilakukan di daerah perkampungan tepatnya posyandu di wilayah binaan Puskesmas Peneleh. Secara geografis luas wilayah Kelurahan Peneleh sekitar 350,54 Ha. Letak Kampung Peneleh perkampungan ini dekat dengan Balai Kota Surabaya dan Monumen Tugu Pahlawan. Letak perkampungan ini termasuk daerah pinggiran kota yakni di pinggir Kalimas. Penduduknya mayoritas dari masyarakat urban dan pemukimannya sangat padat penduduk. Posyandu balita di wilayah binaan Puskesmas Peneleh berjumlah 27 posyandu dengan total bayi usia 0-6 bulan sebanyak 70 bayi.

Posyandu yang menjadi lokasi penelitian ini sebanyak 15 posyandu yaitu posyandu durian1, durian 2, markisa, apel 1, apel 2, anggur 1 dan anggur 2 yang terletak di wilayah peneleh. Sedangkan posyandu aster 1 , aster 2 , flamboyan 1, flamboyan 2 , kemuning 1 , kemuning 2, kenanga 1 dan kenanga 2 terletak di wilayah Kapasari.
Tabel 1. Karakteristik responden di wilayah binaan Puskesmas Peneleh Surabaya pada bulan Januari-Juni 2016

\begin{tabular}{lcc}
\hline \multicolumn{1}{c}{ Karakteristik } & $\mathrm{n}$ & $\%$ \\
\hline Usia & & \\
15-19 tahun & 2 & 4,87 \\
20-29 tahun & 26 & 63,41 \\
30-39 tahun & 11 & 26,82 \\
40-49 tahun & 2 & 4,87 \\
\hline Pendidikan & & \\
SD & 4 & 9,75 \\
SMP & 15 & 36,58 \\
SMA & 18 & 43,90 \\
D3/S1/S2 & 4 & 9.75 \\
\hline Pekerjaan & & \\
Ibu rumah tangga & 35 & 85,37 \\
Wiraswasta & 1 & 2,44 \\
Swasta & 5 & 12,20 \\
PNS & 0 & 0 \\
\hline Budaya & & \\
Jawa & 20 & 48,78 \\
Madura & 20 & 48,78 \\
Budaya lain & 1 & 2,43 \\
\hline Penghasilan keluarga & & \\
< Rp500.000 & 1 & 2,43 \\
Rp 500.000- 1.000.000 & 10 & 24,39 \\
Rp 1.000.000-1.500.000 & 14 & 34,15 \\
>Rp 1.600.000 & 16 & 39,02 \\
\hline
\end{tabular}

Berdasarkan Tabel 1. menunjukkan karakteristik responden sebagian besar berusia 20-29 tahun yaitu 26 responden $(63,41 \%)$, berpendidikan SMA yaitu 18 responden $(43,90 \%)$, memiliki pekerjaan sebagai ibu rumah tangga yaitu 35 responden $(85,37 \%)$, budaya Jawa dan Madura masing-masing 20 responden (Jawa: 48,78\%, Madura: 48,78\%), dan memiliki penghasilan $>\mathrm{Rp}$ 1.600 .000 yaitu 16 responden $(39,02 \%)$.

\section{Data Khusus}

Tabel 2 Gambaran manajemen laktasi di wilayah binaan Puskesmas Peneleh Surabaya bulan Januari-Juni 2016

\begin{tabular}{|c|c|c|}
\hline Karakteristik & $\mathrm{n}$ & $\%$ \\
\hline \multicolumn{3}{|c|}{ Manajemen Laktasi } \\
\hline 1. Baik & 31 & 75,61 \\
\hline 2. Cukup & 10 & 24,39 \\
\hline 3. Kurang & 0 & 0 \\
\hline Total & 41 & 100 \\
\hline
\end{tabular}

Berdasarkan Tabel 2. responden mayoritas menunjukkan manajamen laktasi yang baik yaitu sebanyak 31 responden $(76,61 \%)$.

Tabel 3 Gambaran pertumbuhan bayi usia 0-6 bulan di wilayah binaan Puskesmas 
Peneleh Surabaya bulan Januari-Juni 2016

\begin{tabular}{lcc}
\hline $\begin{array}{l}\text { Pertumbuhan } \\
\text { Bayi }\end{array}$ & $\mathrm{n}$ & $\%$ \\
\hline Status Gizi Lebih & 0 & 0 \\
\hline Status Gizi Baik & 39 & 95,12 \\
\hline $\begin{array}{l}\text { Status Gizi } \\
\text { Kurang }\end{array}$ & 0 & 0 \\
\hline Status Gizi Buruk & 2 & 4,88 \\
\hline Total & 41 & 100 \\
\hline
\end{tabular}

Berdasarkan Tabel 3. menunjukkan mayoritas status gizi pertumbuhan bayi adalah baik sebanyak 39 responden $(95,12 \%)$.

Tabel 4 Hubungan manajemen laktasi dengan pertumbuhan bayi usia 0-6 bulan di wilayah binaan Puskesmas Peneleh Surabaya bulan Januari-Juni 2016

\begin{tabular}{|c|c|c|c|c|c|c|}
\hline \multirow{3}{*}{$\begin{array}{l}\text { Manajemen } \\
\text { Laktasi }\end{array}$} & \multicolumn{4}{|c|}{ Status Gizi } & \multirow{2}{*}{\multicolumn{2}{|c|}{ Total }} \\
\hline & \multicolumn{2}{|c|}{$\begin{array}{l}\text { Gizi } \\
\text { Buruk }\end{array}$} & \multicolumn{2}{|c|}{$\begin{array}{l}\text { Gizi } \\
\text { Baik }\end{array}$} & & \\
\hline & $\mathrm{n}$ & $\%$ & $\mathrm{n}$ & $\%$ & $\mathrm{n}$ & $\%$ \\
\hline Cukup & 2 & 18,2 & 9 & 81,8 & 11 & 100 \\
\hline Baik & 0 & 0 & 30 & 100 & 30 & 100 \\
\hline Jumlah & 2 & 4,9 & 39 & 95,1 & 41 & 100 \\
\hline
\end{tabular}

Hasil uji statistik dengan Spearman Rank Test pada seluruh sampel penelitian menunjukkan nilai $\rho=0,016(\alpha=0,05)$ dan nilai $r=0,374$ yang artinya ada hubungan lemah antara manajemen laktasi dengan pertumbuhan bayi usia $0-6$ bulan.

\section{PEMBAHASAN \\ Manajemen Laktasi}

Berdasarkan tabel 6 sebagian besar ibu menyusui memiliki manajemen laktasi yang baik yaitu sebanyak 31 orang $(75,61 \%)$. Hal ini selaras dengan penelitian Sri Handyani yang menunjukkan manajemen laktasi paling banyak adalah cukup yaitu 32 orang (64\%). Banyak faktor yang mempegaruhi manajemen laktasi. Seperti pada penelitian Irma (2010) menunjukkan bahwa pengetahuan, sikap, nutrisi ibu menyusui, dukungan petugas dan dukungan keluarga berpengaruh terhadap keberhasilan manajemen laktasi.

Manajemen laktasi adalah suatu upaya yang dilakukan oleh ibu, ayah dan keluarga untuk menunjang keberhasilan menyusui. ${ }^{8}$ Manajemen laktasi dimulai dari perawatan payudara sampai pemberian ASI perasan. Keberhasilan dalam menyusui tidak lepas dari faktor internal dan eksternal. Faktor internal berasal dari ibu dan bayi sedangkan faktor eksternal adalah dari lingkungan dan keluarga. Faktor internal sangat mempengaruhi keberhasilan manajemen laktasi. Hal ini sesuai dengan penelitian Sri Handini (2012) yang menggambarkan faktor yang mempengaruhi keberhasilan proses laktasi adalah kondisi dan perawatan payudara, teknik menyusui, posisi menyusui, frekuensi dan durasi menyusui.

Payudara ibu selama menyusui harus dalam kondisi yang baik. Hal ini sejalan dengan penelitian Nur Sholichah (2011) yang menyatakan adanya hubungan antara perawatan payudara ibu postpartum dengan kelancaran pengeluaran ASI. Teknik menyusui yaitu cuci tangan sebelum dan sesudah menyusui akan mencegah tranmisi bakteri, menyusukan payudara secara bergantian akan mencegah pembengkakan payudara, menyusukan payudara sampai areola akan mencegah puting susu lecet, dan menyendawakan bayi akan mencegah aspirasi atau muntah. Posisi menyusui juga tidak kalah penting. Posisi ibu duduk, mensejajarkan telinga dan lengan bayi akan memperlancar proses laktasi. Lama dan frekuensi menyusui yaitu sebaiknya menyusui bayi tanpa dijadwal (on demand). Bayi akan menentukan sendiri kebutuhannya. Menyusui yang dijadwal akan berakibat kurang baik, karena isapan bayi akan mempengaruhi refleks prolaktin dan refleks let down yang berakibat pada produksi ASI selanjutnya. Pengeluaran ASI yaitu apabila payudara bengkak sebaiknya dikeluarkan terlebih dahulu. Dapat dikeluarkan dengan tangan atau dengan pompa. Hal ini akan mencegah bayi tersedak dan enggan menyusu. Penyimpanan ASI perasan sebaiknya tidak diberikan lebih dari 8 jam dan pemberiannya lebih baik dengan sendok atau cangkir agar bayi tidak bingung puting.

Keberhasilan dari manajemen laktasi tidak hanya ditunjang dari faktor internal saja, tetapi juga dari faktor eksternal. Perlunya dukungan keluarga terutama suami, peran serta dari petugas kesehatan dan gencarnya pemakaian sufor harus diminimalisir. Oleh karena itu perawat sebagai health educator sebaiknya memberikan pengetahuan dan penerangan akan keberhasilan manajemen laktasi. Hal ini dapat dilakukan dengan memberikan pelatihan tentang manajemen laktasi yang baik dan benar serat penyuluhan tentang dukungan suami dan dampak sufor bagi pertumbuhan dan perkembangan bayi.

\section{Pertumbuhan Bayi Usia 0-6 Bulan}

Berdasarkan tabel 3 menunjukkan bahwa mayorits pertumbuhan bayi berada pada gizi baik yaitu sebanyak 39 responden $(95,12 \%)$. Hasil ini selaras dengan penelitian Sasti Mega tahun 2012 menunjukkan bahwa rata rata berat badan bayi usia 1-4 bulan, berat badannya lebih besar dari standar deviasinya yaitu $4,1 \mathrm{~kg}$ dengan standar deviasi $0,79 \mathrm{~kg}$. Namun pada penelitian ini juga ditemukan responden dengan status gizi buruk yaitu sebanyak 2 responden $(4,88 \%)$. Hal ini dapat dipengaruhi dari faktor internal dan eksternal khusunya gizi yang diberikan pada bayi.

Pertumbuhan adalah bertambahnya ukuran fisik (anatomi) dan struktur tubuh dalam arti sebagian atau seluruhnya karena adanya multiplikasi (bertambah banyak) sel-sel tubuh dan juga karena 
bertambah besarnya sel. Pemantauan pertumbuhan dapat dilihat dari pengukuran antropometri yaitu berat badan, tinggi badan, lingkar kepala, lingkar lengan atas, dan lipatan kulit. Pertumbuhan akan tampak pada keadaan fisik dan lebih mudah dipantau dengan berat badan. Bayi yang lahir cukup bulan akan kehilangan berat badan sekitar $5-10 \%$ pada 7 hari pertama, dan berat badan waktu lahir akan kembali pada hari ke $7-10 .^{16}$ Pada umur 5 bulan berat badan bayi sudah 2 kali berat badan lahir, dan pada umur setahunsudah 3 kali berat lahir. Menurut jurnal penelitian oleh Wawan Yamarmansyah (2012) mengatakan bahwa berat badan meningkat secara tidak teratur, terutama sekali pada bayi yang disusui. Bila dirata-rata, peningkatan berat badan berkisar pada 150-200 gram per minggu, biasanya melambat setelah usia tiga bulan dan menjadi lambat lagi setelah enam bulan. Tentu saja ada waktu dimana bayi mengalami dorongan pertumbuhan yang cepat dan mengalami kenaikan berat badan atau tumbuh lebih dari biasanya.

Oleh karena itu, pemantauan berat badan secara berkala sangat perlu dilakukan khususnya pada bayi usia 0-6 bulan yang hanya mengkonsumsi ASI. Pemantauan berat badan bayi dapat dilihat dari KMS. Peran perawat sebagai health educator dapat melakukan tindakan penyuluhan kepada kader posyandu untuk lebih memberikan informasi atau memberikan dorongankepada ibu untuk ikut berpartisipasi di posyandu. Dengan ibu yang berpartisipasi aktif di posyandu baik kader ataupun perawat dapat mengetahui atau memantau pemberian ASI eksklusif terhadap peningkatan berat badan bayi tiap bulannya. Sehingga, dengan mengetahui berat badan dapat menentukan pertumbuhan bayi yang dapat dilihat dari status gizi.

\section{Hubungan Manajemen Laktasi Dengan Pertumbuhan Bayi Usia 0-6 Bulan}

Berdasarkan tabel 4 hasil tabulasi silang menunjukkan bahwa mayoritas manajemen laktasi yang baik menunjukkan status gizi yang baik pula yaitu sebanyak 30 responden (100\%) dari 30 responden. Sedangkan manajemen laktasi yang cukup menunjukkan status gizi baik sebanyak 9 responden $(81,8 \%)$ dan status gizi buruk sebanyak 2 responden $(18,2 \%)$ dari 11 responden. Hasil uji statistik menjelaskan adanya hubungan yang signifikan antara manajemen laktasi dengan pertumbuhan bayi usia 0-6 bulan. Bisa dilihat dari tabel hasil spss dengan Spearman Rank Test diperoleh nilai $\rho$ sebesar $0,016(\rho<0,05)$.

Hasil yang signifikan ini dikarenakan manajemen laktasi yang baik dari ibu menyusui akan memacu keluarnya produksi ASI. Produksi ASI yang baik kualitas maupun kuantitasnya dapat memenuhi nutrisi selama pertumbuhan bayi. Hasil penelitian ini sejalan dengan penelitian oleh Heri Triwibowo (2009) yang menyatakan bahwa ibu pasca partum dengan pelaksanaan manajemen laktasi dini secara lengkap dan sesuai protap, memiliki waktu relatif cepat dalam pengeluaran ASI yaitu sebesar 76,19\%. Sedangkan kelompok ibu pasca partum dengan pelaksanaan manajemen laktasi dini secara tidak lengkap atau tidak sesuai protap, memiliki waktu relatif lambat yaitu sebesar $84,62 \%$. Proses laktasi memang erat kaitannya dengan ASI. ASI merupakan salah satu faktor pascanatal yang dapat mempengaruhi pertumbuhan. Seperti pada penelitian oleh Budiwan Putri (2008) menyatakan bahwa bayi yang diberi ASI akan memiliki penambahan berat badan yang baik yaitu sebesar 55,56\%. Kondisi ini disebabkan kandungan nutrisi dari ASI yang mudah dicerna dan diserap oleh bayi. Lemak pada ASI mengandung enzim lipase yang mencerna lemak trigliserida menjadi digliserida. Sehingga sedikit sekali lemak yang tidak diserap oleh sistem pencernaan. ASI yang terserap sempurna akan mempengaruhi status gizi bayi. Semakin banyak ASI yang dikonsumsi makan semakin terpenuhinya nutrisi bayi. Nutrisi yang baik jelas akan mempengaruhi pertumbuhan bayi khusunya penambahan berat badan.

Dari penelitian diatas, menunjukkan bahwa manajemen laktasi dengan prosesnya yang dimulai dari perawatan payudara, perawatan puting, teknik menyusui, lama dan frekuensi, pengeluaran ASI dan penyimpanan ASI jelas dapat mempengaruhi pertumbuhan bayi. Dengan keberhasilan manajemen laktasi, pemberian ASI dapat optimal dan memberikan nutrisi yang optimal pula untuk pertumbuhan. Bertambahanya ukuran, jumlah, dan struktur sel tubuh akan mempengaruhi pengukuran khususnya berat badan dan penentuan status gizi. Namun, pertumbuhan yang dilihat dari status gizi ini harus di pantau setiap bulannya karena berat badan bayi dapat berfluktuasi. Untuk mendukungkeberhasilan manajemen laktasi dan pertumbuhan dengan gizi baik perlu adanya kerja sama yang berkesinambungan yaitu dari ibu, keluarga khusunya suami, petugas kesehatan, kader-kader kesehatan dan pemerintah dalam hal ini untuk meminimalisir gencarnya susu formula untuk bayi usia 0-6 bulan.

\section{SIMPULAN}

1. Sebagian besar responden di wilayah binaan Puskesmas Peneleh Surabaya memiliki manajemen laktasi baik yaitu sebesar $75,61 \%$.

2. Mayoritas responden memiliki pertumbuhan dengan status gizi baik yaitu sebesar $95,12 \%$.

3. Terdapat hubungan antara manajemen laktasi dan pertumbuhan bayi usia $0-6$ bulan terbukti dengan nilai $\rho=0,016(\rho<0,05)$. Hal ini sesuai dengan kenyataan di lapangan bahwa manajemen laktasi yang baik menunjukkan pertumbuhan dengan status gizi yang baik pula.

\section{SARAN}

Pada penelitian selanjutnya yang sejenis perlu memperhatikan kembali karakteristik 
responden khususnya bayi umur 0-6 bulan yang hanya mendapat ASI ekslusif tanpa susu formula ataupun MP-ASI karena akan mempengaruhi pertumbuhan bayi yang dapat dilihat dari status gizi.

Untuk petugas kesehatan, kader posyandu agar dapat mendukung manajemen laktasi yaitu dengan penyuluhan atau pelatihan tentang cara menyusui yang benar dan menggalakkan ASI eksklusif untuk bayi usia 06 bulan.

Untuk masyarakat khususnya orang tua untuk lebih memperhatikan kebutuhan dasar tumbuh khususnya nutrisi bayi sehingga lebih memilih ASI eksklusif untuk bayi usia 0-6 bulan agar berstatus gizi baik.

Untuk instasi pendidikan diharapkan mampu menunjang pengembangan ilmu manajemen laktasi yaitu dengan meningkatkan jumlah referensi atau literatur yang ada diperpustakaan.

\section{DAFTAR PUSTAKA}

1. Edining Tyas, Budiwan Putri. 2013. Hubungan antara pemberian ASI ekslusif dan ASI non eksklusif dengan pertumbuhan berat badan 0-6 bulan di desa giripurwo, wonogiri. http://eprints.ums.ac.id/22730/. diunduh tanggal 1 Mei 2016 jam 00:08 WIB

2. Hamadun, Sulimah. 2013. Social Determinant Facyors Affecting Lactation Managment In Pregnant Women In Work Healt Center Kalumata Southern Diztrict of Ternate InNorth Maluku Citty of Ternate. http://pasca.unhas.ac.id/jurnal/files/e4c9b9a9b e2a99d654f2ce17bec782fa.pdfdiunduh tanggal 20 Maret 206 jam 15.00 WIB

3. Handayani, Sri. 2015. Hubungan Pengetahuan Ibu Tentang Manajemen Laktasi Dengan Perilaku Dalam Pemberian ASI Di Desa Kenokorejo Polokarto Sukoharjo. http://stikeskusumahusada.ac.id/digilib/downlo ad.php?id=1320. diunduh tanggal 21 Juni 2016 jam 11:36 WIB

4. Heriyanto, Bambang. 2012. Metode Penelitian Kuantitatif. Surabaya : Putra Media Nusantara.

5. Hidayat, Aziz Alimul A. 2012. Pengantar Ilmu Keperawatan Anak. Jakarta : Salemba Medika

6. Nursalam. 2008. Asuhan Keperawatan Bayi dan Anak (untuk perawat dan bidan). Jakarta : Salemba Medika

7. Pertiwi, SH. 2012. Faktor-Faktor yang Mempengaruhi Proses Laktasi Ibu dengan Bayi Usia 0-6 Bulan di Desa Cibeusi Kecamatan Jatinagor. jurnal.unpad.ac.id/ejournal/article/download/6 97/743. diunduh tanggal 20 Maret 2016 jam 15 :21 WIB

8. Prasetyono, Dwi Sunar. 2012. Buku Pintar Asi Eksklusif. Jogyakarta: Diva Press

9. Proverawati, Atikah. 2010. Kapita Selekta ASI dan Menyusui. Jogjakarta : Nuha Medika
10.

Kesehatan Pusdatin Kemenkes. 2015. Profil 2014.http://www.depkes.go.id/resources/downl oad/pusdatin/profil-kesehatan-indonesia/profilkesehatan-indonesia-2014.pdf.diunduh tanggal 21 Maret 2016 jam 1:42 WIB

11. Rachmaniyah, N. 2014. Hubungan Antara Tingkat Pendidikan Ibu dengan Komitmen pemberian ASI Eksklusif. http://eprints.umpo.ac.id/1366/4/BAB\%20I.pdf. diunduh tanggal 21 Maret 2016 jam 5:45 WIB

12. Rahayu, A.Bekti. 2015.Hubungan Tingkat Pendidikan Ibu dengan Komitmen Pemberian ASI

Ekslusif. http://eprints.umpo.ac.id/1366/4/BAB\%20I.pdf, diunduh tanggal 21 Maret 2013 jam $15: 29$ WIB.

13. Sari, Yustisia D. 2014. Persepsi ibu menyusui mengenai kampanyeasi ekslusif dipuskesmas jagir surabaya. http://repository.petra.ac.id/16715/1/Publikasi 1_09003_1616.pdf. diunduh tanggal 27 Maret 2016 jam $13: 04$ WIB

14. Sholichah, Nur. 2011. Hubungan Perawatan Payudara Pada Ibu Post Partum Dengan Kelancaran Pengekuaran ASI Di Desa Karang Duren Kecamaran Tenggaran Kabupaten Semarang. $\quad$ http://e-journal.akbidpurworejo.ac.id/index.php/jkk3/article/view/52. diunduh tanggal 13 Juni 2016 jam 23:11 WIB

15. Soetjiningsih. 1997. ASI: Petunjuk Untuk Tenaga Kesehatan. Jakarta : EGC

16. Soetjiningsih. 2012. Tumbuh Kembang Anak Edisi 2. Jakarta : EGC

17. Sugiyono. 2010. Metode Penelitian Kuantitatif dan Kualitatif dan R\&D. Bandung: Alfabeta

18. Suminar, Sasti Mega. 2012. Hubungan Pola Pemberian ASI dengan Peningkatan Berat Badan Bayi. http://pmb.stikestelogorejo.ac.id/ejournal/index.php/ilmukeperawatan/article/vie $w / 190 / 214$.diunduh tanggal 13 Juni 2016 jam 12:34 WIB

19. Tribowo, Heri, Catur Prasatia Lukita. 2008. Hubungan penatalaksanaan manajemen laktasi dini dengan waktu keluarnya ASI pada ibu pasca partum dirumah bersalin ananda mojokerto. http://ejournal.stikesppni.ac.id/index.php/keperawatan-binasehat/article/view/66\%20Cache . diunduh tanggal 13 juni 2016 jam 23:11 WIB

20. Verralls, Sylvia. 1997. Anatomi Dan Fisiologi Terapan Dalam Ilmu Kebidanan. Jakarta : EGC

21. WHO. 2010. Chart Berat Badan Menurut Umur.

http://who.int/childgrowth/standards.diunduh tanggal 6 Juni 2016 jam 11:36 WIB

22. Wong D. L.,Whaly. 2004. Buku Ajar Keperawatan Pediatrik, Alih bahasa Sunarno,Agus dkk.Edisi 6 Volume 1.Jakarta :EGC. 
23. Yamarwansyah, wawan. 2012. Hubungan ASI dengan Penambahan Berat Badan Bayi. http://dokumen.tips/documents/hubungan-asidengan-penambahan-berat-badan-bayi.html. diunduh tanggal 13 Juni 2016 jam 15:12 WIB

24. Yani, Irma. 2010. Faktor-Faktor Yang Mempengaruhi Perilaku Ibu Laktasi Dalam Memberikan ASI Di 6 Kabupaten/Kota Di Provisni Sumatera Barat. http://ejournal.litbang.depkes.go.id/index.php/ pgm/article/view/1459/2929.diunduh tanggal 23 Juni 2016 13:21 WIB 